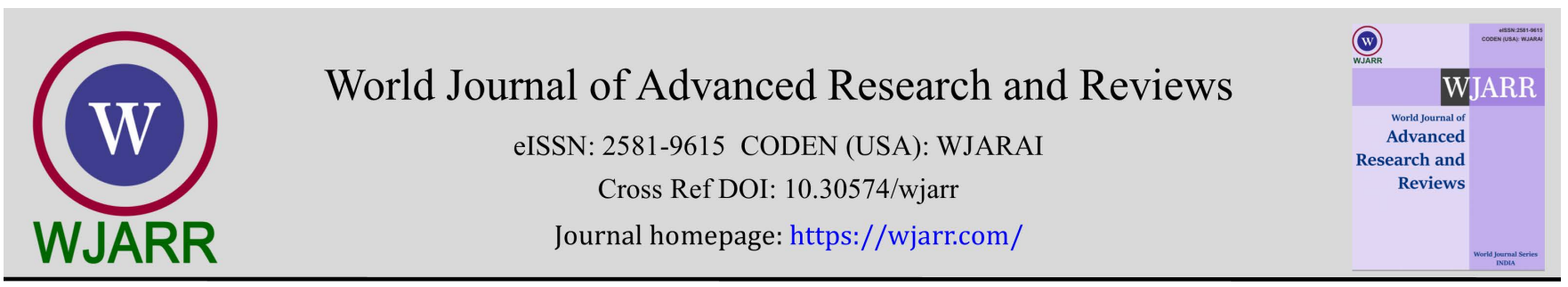

(RESEARCH ARTICLE)

\title{
Frog trade: A reality in Abidjan district, Ivory Coast
}

\author{
Blayda Tohe*, Phoebe Son and Romaric Konate Beh \\ Training and Research Unit-Environmental Sciences and Management, Nangui Abrogoua University, Ivory Coast.
}

World Journal of Advanced Research and Reviews, 2022, 13(02), 371-376

Publication history: Received on 22 November 2022; revised on 19 February 2022; accepted on 21 February 2022

Article DOI: https://doi.org/10.30574/wjarr.2022.13.2.0651

\begin{abstract}
In Côte d'Ivoire, the marketing of edible frogs, although still an informal activity, constitutes a source of income for the population. In fact, the survey conducted between February and June 2020 in the markets of the communes of Yopougon, Abobo and Port-Bouët in the district of Abidjan recorded a total of 60 sellers, including 32 in Yopougon 16 in Abobo and 12 in Port-Bouët. The species sold is Hoplobatrachus occipitalis. In this activity, single women represent $54 \%$ against $33 \%$ for brides and $13 \%$ for widows. However, $60 \%$ of sales women find this activity unprofitable against $40 \%$ who find it profitable. Whatever the municipality, the Yacouba (33\%) and Guéré (27\%) peoples, from the west of the country who traditionally eat frogs, dominate the market for the sale of these animals.
\end{abstract}

Keywords: Trade in frogs; Edible frogs; Hoplobatrachus occipitalis; Informal activity; Municipalities of the district of Abidjan

\section{Introduction}

The consumption of frogs is a well-recognized reality these days. Indeed, Nigroni [1] reported that the annual demands of frogs on the international market for human consumption which were respectively 20000, 2000 and 500 tones for the United States, France and Italy were met by wild frogs captured in the wild. In addition, Neveu [2] indicated that around fifty species were consumed around the world. In Africa in particular, frogs constitute a very important food resource [3]. Indeed, they represent an essential means of subsistence in rural communities [4]. According to Mohneke et al. [5], the frog trade is very flourishing in many West African countries, particularly in Burkina Fasso, Benin and Nigeria where these animals are sold dry or fried. In western Cameroon and eastern Nigeria, tadpoles are even captured for food [5]. This demonstrates an overexploitation of this resource. Hoplobatrachus occipitalis is the most commonly eaten species. Recall that to date, no regulations govern the exploitation of frogs in the sub-Saharan zone. So Hoplobatrachus occipitalis is sold in virtually every West Africa market dry or fresh. In Côte d'Ivoire, to date, very little data on the sale and the consumption of frogs $[6,7]$ are available. They report the consumption of frogs in the central west and west of the country. As for their marketing in Abidjan, the country's economic capital, it still remains an unknown. So we found sensible to check the reality of this trade in a few municipal markets of the district of Abidjan.

\section{Material and methods}

\subsection{Study site}

Our investigation took place in the markets of Abobo, Port-Bouet and Yopougon, three communes of Abidjan district (Fig. 1) which has thirteen.

\footnotetext{
* Corresponding author: Tohe Blayda

Training and Research Unit-Environmental Sciences and Management, Nangui Abrogoua University, Ivory Coast. 
This choice was guided by the strategic position of these three municipalities and their importance at the demographic level. Indeed, they constitute the three main entrances to the economic capital of our country. Abobo is located in the North, Yopougon in the West and Port-Bouët in the South. According to the 2014 census, the official population is 1.071.543 inhabitants for Yopougon, 1.030 .658 for Abobo and 419.033 for Port-Bouët. As for the geographical coordinates, the markets of Abobo, Port-Bouët and Yopougon are located respectively between $5^{\circ} 25^{\prime} 38^{\prime \prime} \mathrm{N}-4^{\circ} 0$ '55" $\mathrm{W}, 5^{\circ} 15^{\prime} 31^{\prime \prime} \mathrm{N}-3^{\circ} 57^{\prime} 51^{\prime \prime} \mathrm{W}$ and $5^{\circ} 21^{\prime} 19^{\prime \prime} \mathrm{N}-4^{\circ} 4^{\prime} 34^{\prime \prime} \mathrm{W}$.

\subsection{Methodology}

The data collection took place between February and June (the end of the great dry season and the start of the great rainy season) 2020. It consisted in finding in these three markets the sellers of frogs and asking them a series of questions relating to their age, ethnicity, marital status, the origin of the frogs sold and the profitability of this activity.
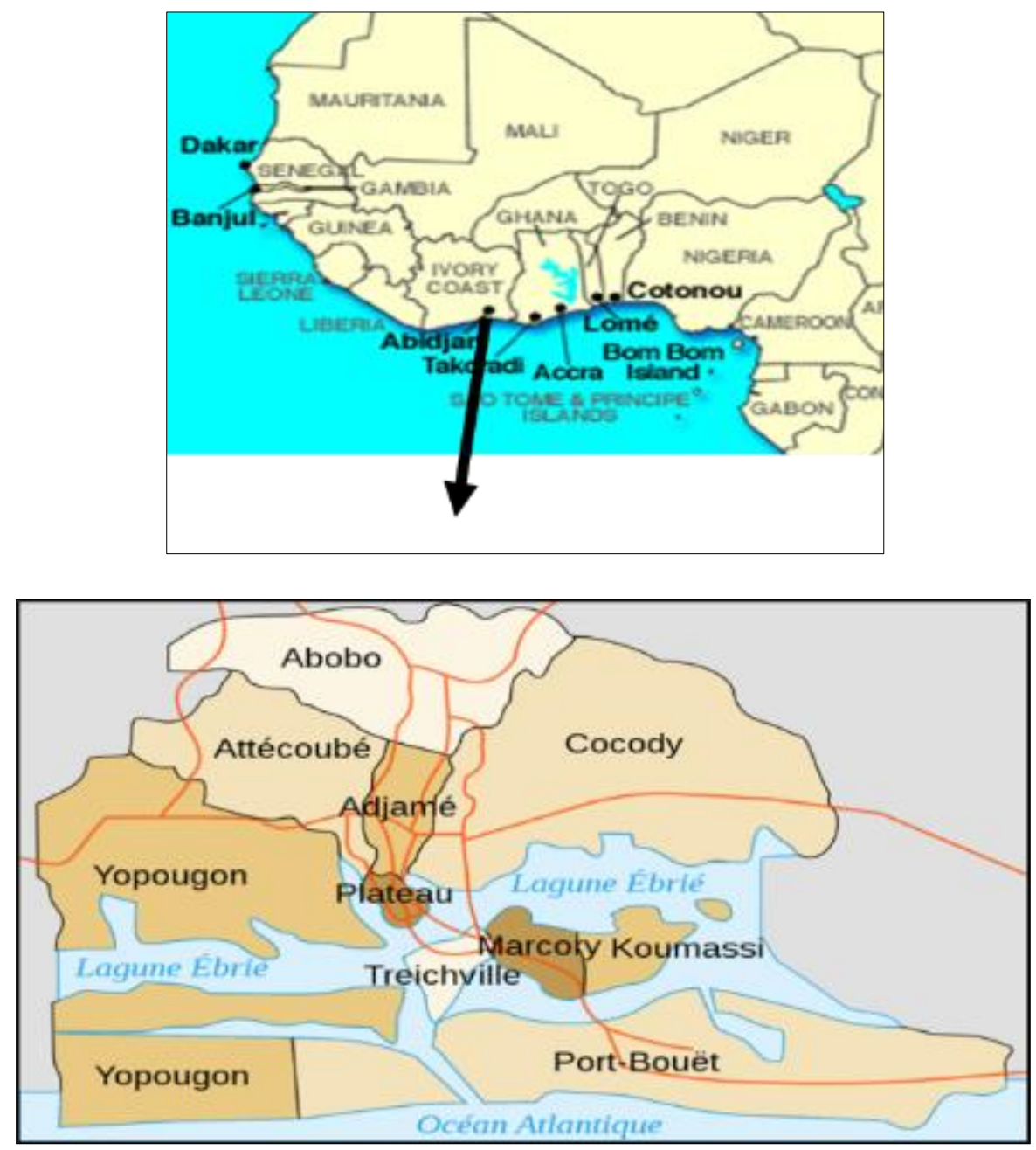

Figure 1 Map of the city of Abidjan with its different municipalities. $\square$ The markets visited

\section{Results}

\subsection{Distribution of saleswomen by municipality}

A total of 60 frog sellers were identified in the three communes of the district of Abidjan. The largest work force is found in the commune of Yopougon with 32 saleswomen (53\%) followed by Abobo (16 saleswomen: 27\%) and Port-Bouët (12 saleswomen: 20\%) (Fig. 2). 


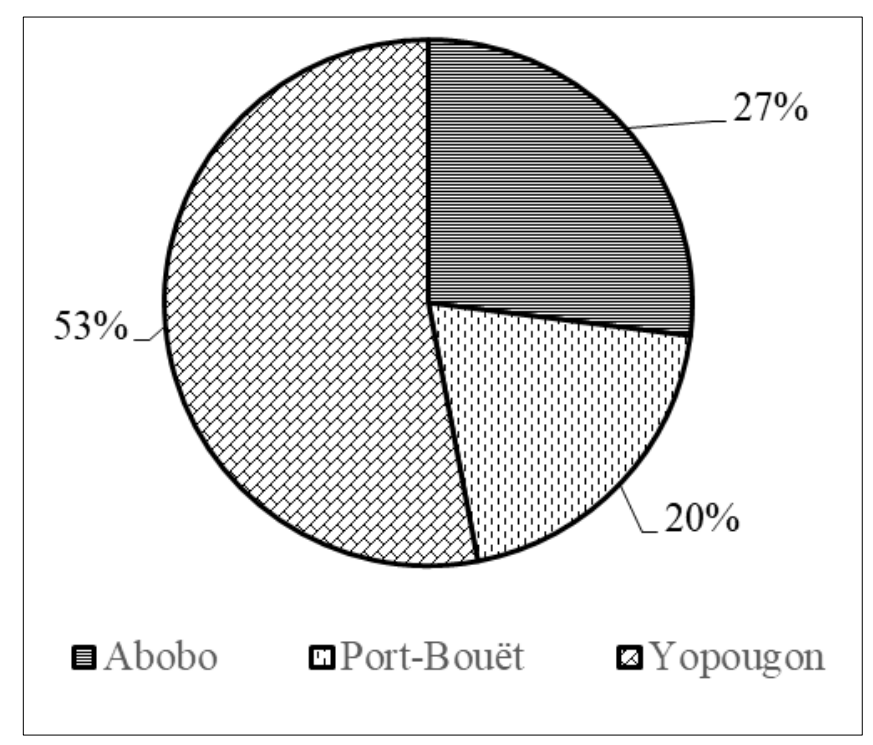

Figure 2 Distribution of frogs' sellers in the three communes of the district of Abidjan

At the marital level (Fig. 3A), single women represent 54\% (32 saleswomen) of the workforce and married women and widows represent respectively 33\% (20 saleswomen) and 13\% (8 saleswomen). Regarding the distribution by municipality (Fig. 3B), married women are present in the three municipalities with the majority in Port-Bouët (50\%). As for unmarried women and widows, they are absent respectively in Port-Bouet and Abobo. While in Port-Bouët there are as many brides as single people involved in the frog trade, in Abobo and Yopougon single women are in the majority with respective proportions of $75 \%$ and $62.5 \%$.

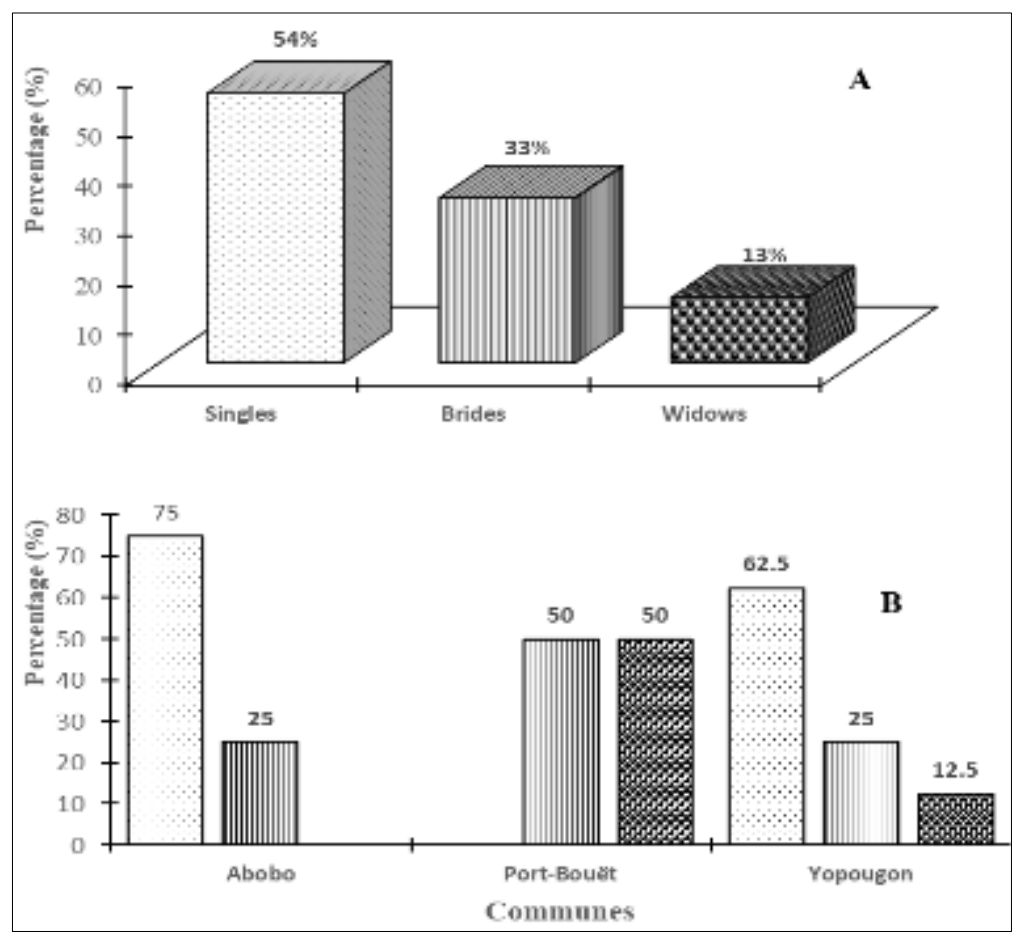

Figure 3 Distribution of saleswomen by marital status (A) and by municipality (B). 
Figure 4 shows photos taken in the different municipalities where the survey took place.

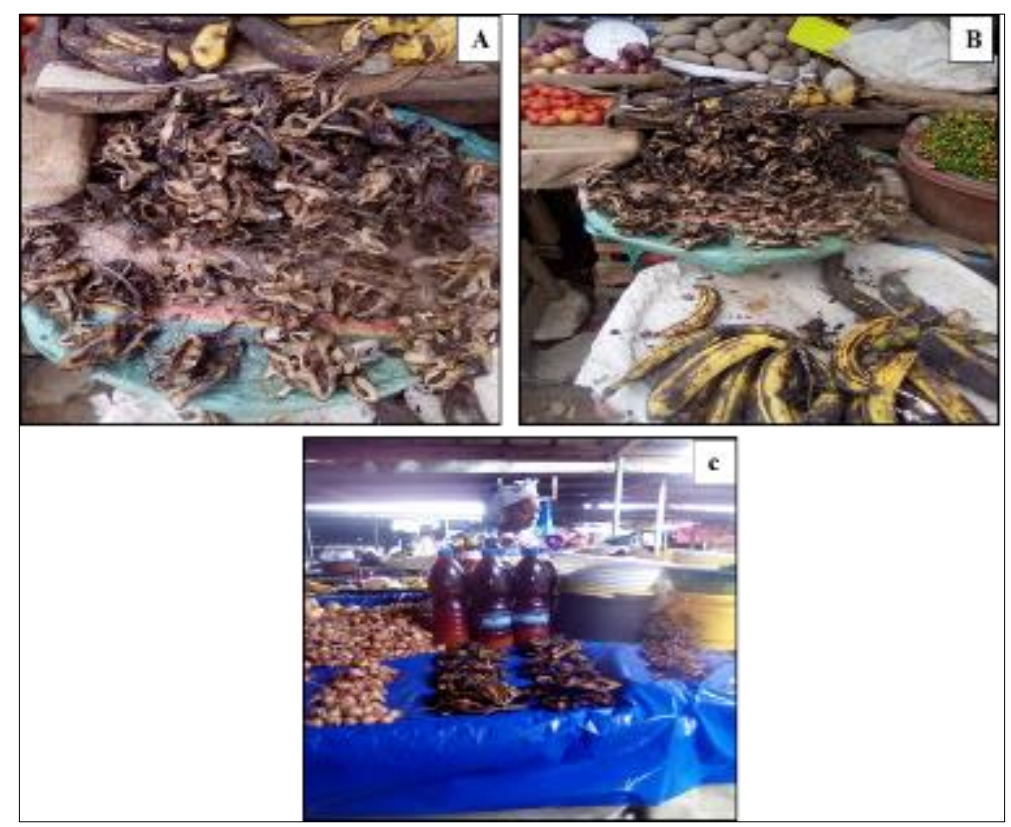

Figure 4 Sale of Hoplobatrachus occilpitalis in the communes of Yopougon (A), Abobo (B) and Port-Bouët (C). Batches of seven to eight dried adult specimens are sold for 1000.00 FCFA (approx. 1.64 USD)

Table 1 summarizes the number of children in charge of frog sellers in the three communes of the district of Abidjan. The average of children in care is higher among single women (4) than widows (3) and married (2).

Table 1 Number of children in care

\begin{tabular}{|l|c|c|}
\hline & Number of children in care & Average of children \\
\hline Single & $1-7$ & 4 \\
\hline Brides & $1-4$ & 2 \\
\hline Widows & $1-4$ & 3 \\
\hline
\end{tabular}

As for profitability (Figure 5), 40\% of saleswomen ( 24 women) are satisfied with this activity and $60 \%$ (36 saleswomen) find it unprofitable. However, for all these women, the sale of frogs is a secondary activity.

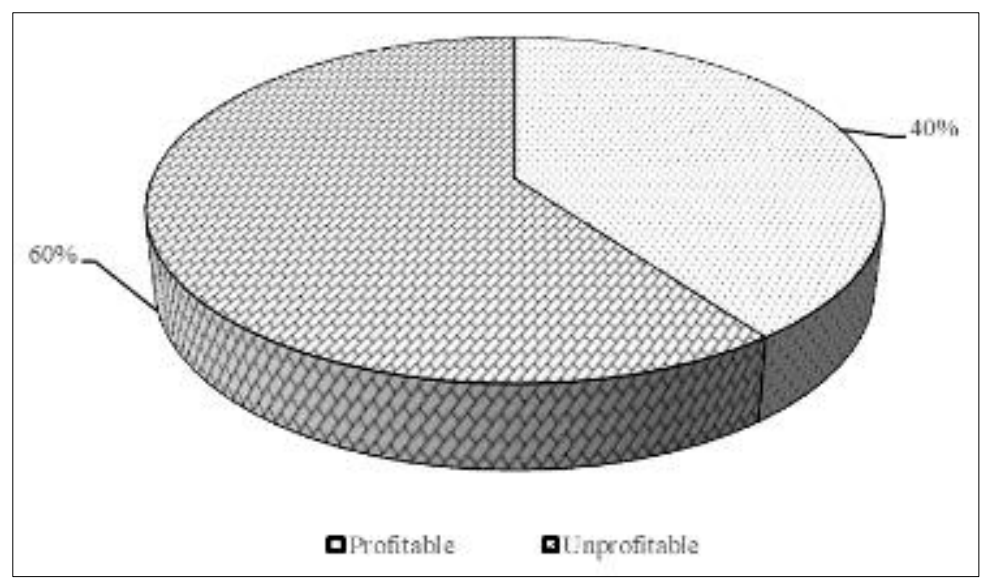

Figure 5 Representation of the profitability of the frog trade 
Six ethnic groups (Figure 6) are involved in the frog trade in these three markets in the district of Abidjan (out of the sixty ethnic groups in the country). The Yacouba (33\%) are the most represented. They are followed by Guéré $(27 \%)$ then Bété and Gouro (13\%) and finally Baoulé and Wobé (7\%).

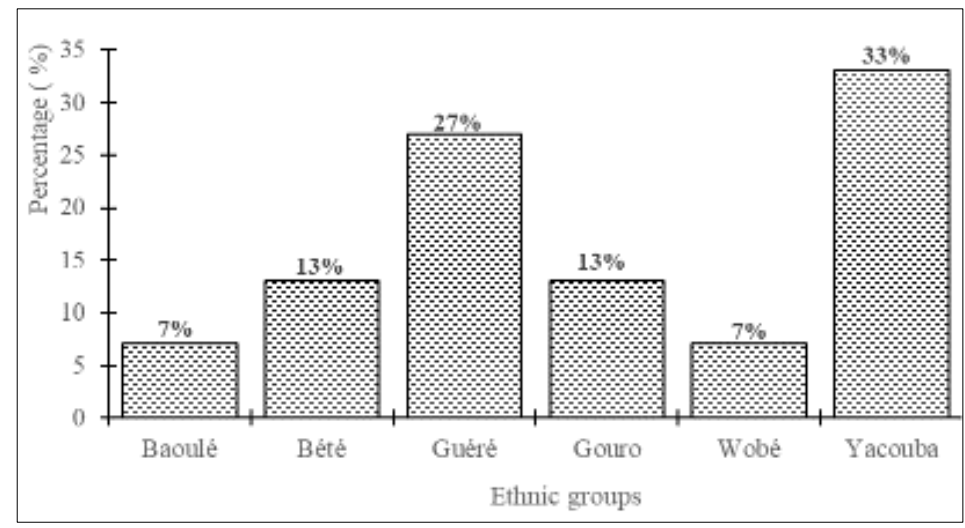

Figure 6 Distribution of frog sellers by ethnic group

Figure 7 shows the proportions of frogs sold by season in the municipalities of Abobo, Port-Bouët and Yopougon. Whatever the municipality, the quantities of frogs sold are significant in the rainy season (68 to $76 \%$ ) than in the dry season (24 to $32 \%)$.

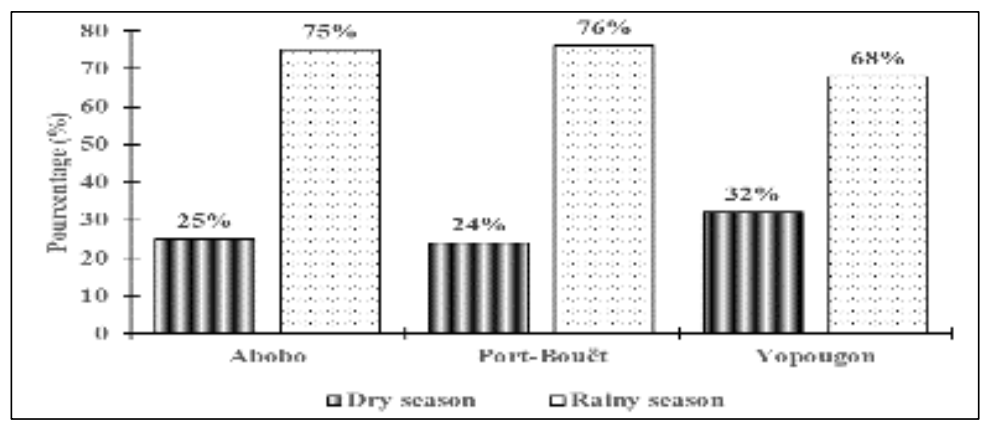

Figure 7 Seasonal distribution of the quantities of frogs sold per municipality

\section{Discussion}

The sale of frogs is a reality that was observed in the markets of Abobo, Port-Bouët and Yopougon which were visited. The number of sales women is decreasing from Yopougon (53\%) to Port-Bouët (20\%) via Abobo (27\%). These high numbers observed especially in Yopougon and Abobo can be explained partly by the high density of population in these two municipalities. Indeed, Yopougon is the most populated municipality of district of Abidjan. In addition, the residents of the locality of Yopougon come mostly from the western region of the country which is a region traditionally recognized as a consumer of frogs. In Côte d'Ivoire, to date, only Kouamé et al. [6] and Blé et al. [7] who respectively observed the sale of frogs in the markets of Daloa (in the midwest of the country) and their consumption in the west in the localities of Man, Zoukougbeu, Issia, Guessabo and Daloa are available. They report in particular that in the west of the country, frog meat is a very popular source of animal protein that is part of the eating habits of people. It is also from this region that are native Yacouba and Guéré, who are the most involved ethnic groups in this trade of frogs. Our results show that the quantities of frogs sold in the rainy season are more important than those of the dry season. Indeed, during the rainy season, frogs come out of their hiding places for reproduction. This season would therefore be in favor of increasing their numbers in the ponds. This result corroborates the observations of Akani et al. [8], Adeba [9] and Onadeko et Ogoanah [10] who report that frog activity is more intense during rainy seasons. This large number of frogs during the rainy season may also be attributable to the availability of the insects which constitute their essential prey. Indeed, Tohé [11] report in Banco National Park that in Hoplobatrachus occipitalis, the proportion of insects in stomach contents during rainy seasons is greater than that in dry seasons. This significant difference according to these authors is due to the availability of insects which are more abundant in the environment during the rainy season. In particular, Dietoa [12] reports that reproduction in most insects coincides with the rainy season. It is precisely during the rainy season when there is an abundance of frogs that the trade is profitable for the sellers. 


\section{Conclusion}

This study clearly shows that the populations of Abobo, mostly originating from the west of the country, where frogs are traditionally eaten, are the most involved in this trade in the district of Abidjan. Single women with an average of four children are the most represented in this activity which is quite profitable.

\section{Compliance with ethical standards}

\section{Acknowledgments}

At the end of this work, we would like to thank all the women who facilitated the survey in the various markets visited. We are also grateful to the various authorities who have supported us in our work. We do not want to name any name for fear of forgetting one. Thanks also to Professor KOUAME (Jean LOROUGNON GUEDE University, Daloa) for his help.

\section{Disclosure of conflict of interest}

This article was initiated by Mr. Blayda TOHE. It is part of a larger research project of which he is the promoter and there is no conflict of interest.

\section{Statement of informed consent}

This work required interviews with female frog sellers in three large markets in the district of Abidjan. These people are anonymous and it is precisely for this reason that no name has been mentioned in this manuscript.

\section{References}

[1] Nigroni G. Frog culture. World aquaculture. 1997; 28 (1): 16-22.

[2] Neveu A. La raniculture est-elle une alternative à la récolte? Etat actuel en France. INRA. Prod. Anim. 2004; 17: 167-175.

[3] Mohneke M, Onadeko AB, Rödel MO. Medecinal and dietary uses of amphibians in Burkina Faso. African Journal of herpetology. 2011; 60(1): $78-83$.

[4] Tohé B, Assemian NE, Kouamé NG. Reproduction of African Tigrine Frog Hoplobatrachus occipitalis in Banco National Park (Ivory Coast). International Journal of Science and Research. 2016; 5(1): 577- 581.

[5] Onadeko AB, Egonmwan RI, Saliu JK. Edible amphibian species: local knowledge of their consumption in south west Nigeria and their nutritional value. West African journal of applied ecology. 2011; 19(1): 67-76.

[6] Blé YC, Yobouet BA, Dadié A. Consumption, proximate and mineral composition of edible frog Hoplobatrachus occipitalis from midwest areas of Côte d'Ivoire. African Journal of Science and Research. 2016; 5(3): 16-20.

[7] Kouamé NG, Caleb OB, Adum GB, Gourène G, Rödel MO. The anuran fauna of a West African urban area. Amphibian \& Reptile conservation. 2015; 9(2): 1-14.

[8] Akani GC, Politano E, Luiselli L. Amphibians recorded in forest swamps areas of the River Niger Delta (Southeastern Nigeria) and effects of habitat alterations from oil industry development on species richness and diversity. Applied Herpetology. 2004; 2: 1-22.

[9] Adeba JP. Diversité biologique et quelques données écologiques sur le peuplement des anoures de la région de Lamto. [Thèse de Doctorat]. Université Félix Houphouët-Boigny, Côte d'Ivoire. 2013.

[10] Onadeko AB, Ogoanah OS. Habitat selection of four African Tree frogs (Leptopelis boulengeri, Hyperolius burtoni, H. guttulatus and Afrixalus dorsalis) in degraded environnements of the Nigeria Delta, Nigeria. Journal of Research in Forestry, Wildlife and Environnement. 2016; 8(1): 27-44.

[11] Tohe B. Reproduction et régime alimentaire de trois espèces d'Anoures des habitats dégradés du parc national du Banco (Côte d'Ivoire): Ptychadena mascareniensis, P. pumilio et Hoplobatrachus occipitalis. [Thèse de doctorat]. l'Université Abobo-Adjamé, Côte d'Ivoire. 2009.

[12] Dietoa YM. Entomofaune et stratégie alimentaire des poissons du genre Brycinus (Characidae) en milieux fluviatiles et lacustres (Bassins Bia et Agnebi; Côte d'Ivoire. [Thèse de doctorat]. Université Abobo-Adjamé, Côte d'Ivoire. 2002. 